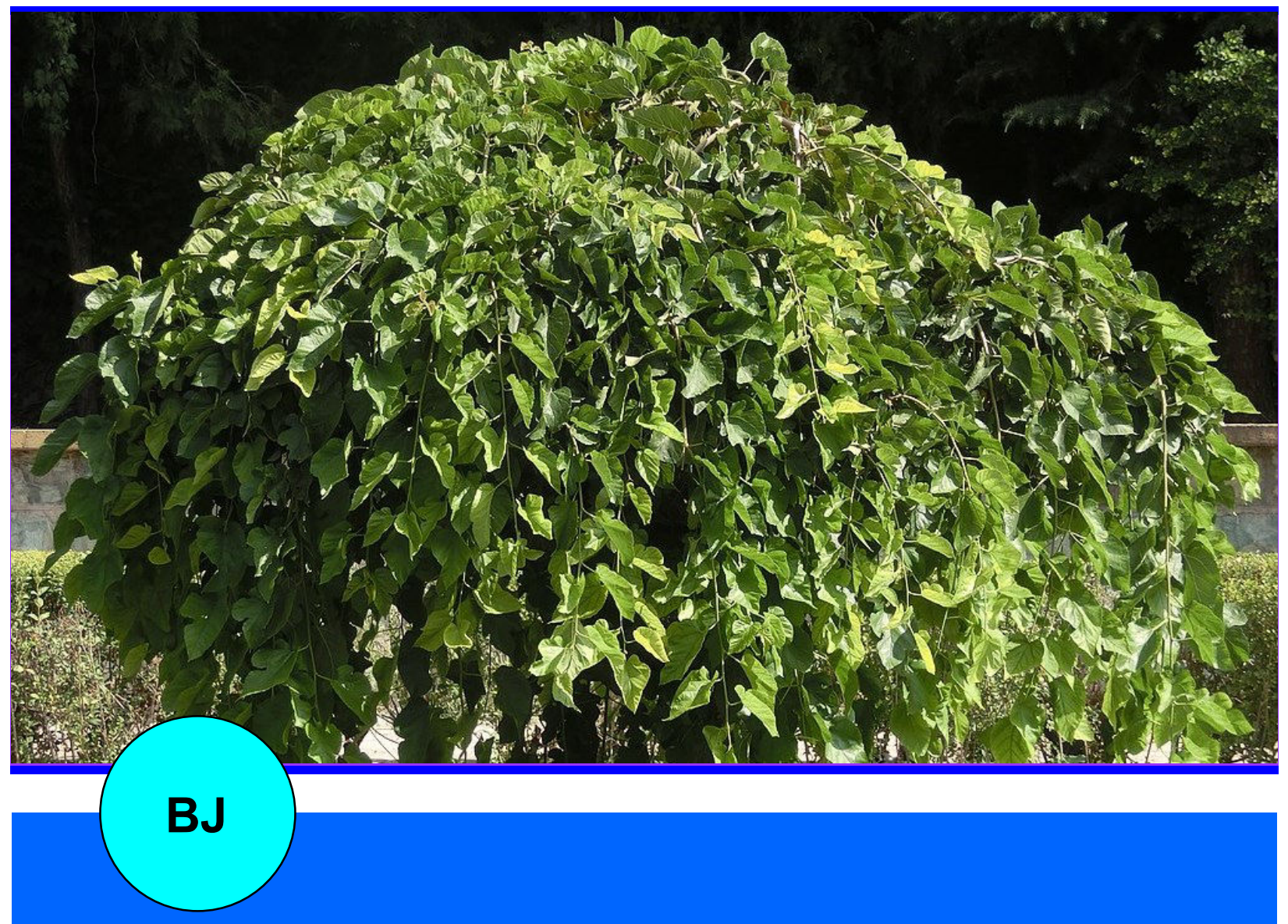

Bangladesh Journal of Pharmacology

Research Article

Pharmacological basis for the medicinal use of Morus alba in gut and airways disorders 


\title{
Pharmacological basis for the medicinal use of Morus alba in gut and airways disorders
}

\author{
Munasib Khan',2, Najeeb-Ur-Rehman', Arif-Ullah Khan' ${ }^{3}$ and Anwarul-Hassan Gilani' \\ ${ }^{1}$ Natural Products Research Unit, Department of Biological and Biomedical, Sciences, The Aga Khan University \\ Medical College, Karachi 74800, Pakistan; ${ }^{2}$ Department of Pharmacy, University of Malakand, Chakdara, Dir Lower, \\ Pakistan; ${ }^{3}$ Department of Pharmacy, Kohat University of Science and Technology, Kohat 26000, Pakistan.
}

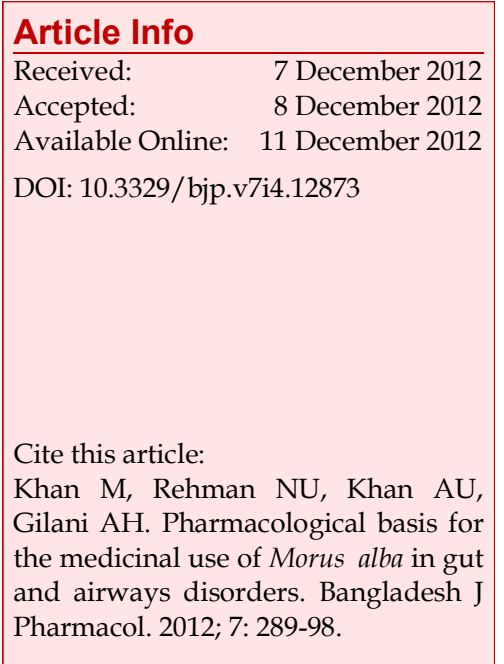

\begin{abstract}
Crude extract of Morus alba at $100 \mathrm{mg} / \mathrm{kg}$ exhibited protective effect against castor oil-induced diarrhea in mice. In isolated rabbit jejunum, M. alba (0.3-10 $\mathrm{mg} / \mathrm{mL}$ ) inhibited the spontaneous contractions and caused glibenclamidesensitive inhibition of low $\mathrm{K}^{+}(20 \mathrm{mM})$-induced contractions, with mild effect on high $\mathrm{K}^{+}(80 \mathrm{mM})$. Similarly, cromakalim caused inhibition of low $\mathrm{K}^{+}$, but not of high $\mathrm{K}^{+}$, while verapamil did not differentiate in its inhibitory effect on two concentrations of $\mathrm{K}^{+}$. M. alba $(3.0-30 \mathrm{mg} / \mathrm{kg})$ caused suppression of carbachol $(100 \mu \mathrm{g} / \mathrm{kg})$-induced increase in inspiratory pressure of anaesthetized rats. In guinea-pig trachea, M. alba completely inhibited low $\mathrm{K}^{+}$ contractions, with partial effect on high $\mathrm{K}^{+}$. M. alba $(0.3-1.0 \mathrm{mg} / \mathrm{mL})$ caused leftward shift of isoprenaline-induced inhibitory concentration response curves, like papaverine. These results indicate that $M$. alba possesses a combination of $\mathrm{K}_{\text {ATP }}$ channel opening, weak $\mathrm{Ca}^{++}$-antagonist and phosphodiesterase inhibitory mechanisms, which explain its medicinal use in hyperactive gut and airways disorders.
\end{abstract}

\section{Introduction}

Morus alba Linn. (Family:Moraceae), commonly known as "Mulberry" and locally, "Shahtut" is found in Khyber Pakhtunkhwa, Punjab and Baluchistan provinces of Pakistan and other parts of the world. It is a medium sized tree, 3-6 m high with whitish or dark purple fleshy fruits, $1.5-3 \mathrm{~cm}$ long and edible (Baquar, 1989). M. alba is used in folk medicine to treat diarrhea, asthma, cough, dyspepsia, eye problems, intestinal ulcers, headaches, hemoptysis, hepatopathy, hoarseness, lumbago, melancholia, scabies, smallpox and splenopathy (Baquar, 1989; Brown, 1995; Shinwari et al., 2003; Deshpande et al., 2008) as well as considered useful as anthelmintic, antibacterial, aphrodisiac, antirheumatic, diuretic, expectorant, antihypertensive, laxative and sedative agent (Nadkarni, 1976; Chiej 1984; Duke and Ayensu, 1985; Bown, 1995; Usmanghani et al., 1997;
Wiart, 2002).

Phytochemical studies on the plant revealed the presence of numerous constituents that include sugar, pectin, citrates, malates, phytosterol, sulfur, essential oils, quercetin, inokosterone, ecdysterone, phytosterol, rutin, morocetin, isoquercitrin, umbelliferone, scopolin, hexenal, trigonelline, choline, adenine, aspartic acid, chlorogenic acid, phytosterol, deoxynojirimycin, moracetin, gamma amino butyric acid, sitosterol, fiber, calcium, vitamin A, vitamin B1, vitamin B2, vitamin C, sodium, potassium, carotenes, amino acids, prenylflavones, glycoside, astragal, scopolin, skimmin, roseoside II and benzyl D-glucopyranoside (Nadkarni, 1976; Doi et al., 2001).

M. alba is reported to possess antidiabetic (Chen et al., 1995), anti-inflammatory (Hong et al., 2002; Choi and Hwang, 2005), hepatoprotective (Oh et al., 1999), anti- 
melanocytic (Baurin et al., 2002; Lee et al., 2002), anticancer (Kim et al., 2000), antihyperlipidimic (Doi et al., 2001) properties. In present research, we provide evidence that $M$. alba exhibits antidiarrheal, antispasmodic and bronchodilatory activities, mediated through $\mathrm{K}^{+}$channel activation, weak $\mathrm{Ca}^{++}$channel blockade (CCB) and phosphodiesterase (PDE) inhibitory pathways, which explains the medicinal use of $M$. alba in hyperactive gut and airways disorders, such as diarrhea and asthma.

\section{Material and Methods}

\section{Plant material and extraction}

The fresh fruit of M. alba was collected from the trees in April 2008. The plant material was cleaned and approximately $1.7 \mathrm{~kg}$ of the material was soaked in aqueous-methanol $(70 \%)$ at room temperature $\left(25 \pm 2.0^{\circ}\right.$ C) for 24 hours with occasional shaking. It was passed through a clean muslin cloth and then through filter paper. This procedure of soaking and filtration was repeated twice more (Williamson et al., 1998). All the filtrates were combined and evaporated to dryness on a rotary evaporator under reduced pressure $(-760 \mathrm{mmHg})$ at $35-40^{\circ} \mathrm{C}$ to a semisolid residue of light brown color with sweetish aroma, the crude extract of M. alba, yielding approx. $14.6 \%$. M. alba was soluble in normal saline $(0.9 \%)$ and distilled water for use in the in vivo and in vitro experiments.

\section{Animals}

Rabbits (1-1.2 kg), guinea-pigs (500-550 g), SpragueDawley rats (200-250 g) and Balb-C mice (20-25 g) of local breed and either sex were used for this study housed at the Animal House of the Aga Khan University, maintained at $23-25^{\circ} \mathrm{C}$ and were given a standard diet and tap water. Rabbits starved for 24 hours were sacrificed by blow on back of head. Experiments performed complied with rulings of Institute of Laboratory Animal Resources, Commission on Life Sciences, National Research Council, 1996).

\section{Chemicals}

Acetylcholine chloride (ACh), carbachol (CCh), isoprenaline, loperamide, glibenclamide, papaverine, potassium chloride and verapamil were obtained from Sigma Chemicals Co, St Louis, MO, USA and cromakalim from Tocris, Ellisviille, MO, USA. Pentothal sodium (thiopental) and castor oil were respectively obtained from Abbot Laboratories and KCL Pharma, Karachi, Pakistan. Chemicals used for making physiological salt solutions were: Calcium chloride, glucose, magnesium chloride, magnesium sulfate, potassium dihydrogen phosphate, sodium bicarbonate, sodium dihydrogenphosphate (Merck, Darmstadt, Germany and sodium chloride from BDH Laboratory supplies,
Poole, England. The chemicals used in phytochemical analysis include: Acetic anhydride, aluminum chloride, ammonium hydroxide, ferric chloride (Sigma Chemical Co, USA), benzene, chloroform, hydrochloric acid and petroleum ether (BDH Laboratory Supplies, England). All chemicals used were of analytical grade.

\section{Phytochemical screening}

Preliminary investigation of the plant extract for the presence of various phytochemical classes, such as saponins, coumarins, sterols, terpenes, flavonoids, anthraquinones and tannins was done according to reported methods (Edeoga et al., 2005). Plant material was noted as positive for flavonoids when it gave yellow color with aluminum chloride reagent and for tannins, when green or black color was produced with aqueous ferric chloride. For the detection of sterols and terpenes, plant material was treated with petroleum ether and subsequently extracted with chloroform. The appearance of green to pink (for sterols) and pink to purple colors (for terpenes) was then noted after treatment of chloroform layer with acetic anhydride and concentrated hydrochloric acid in succession. Presence of saponins was based on the appearance of froth upon vigorous shaking of diluted samples. The observation of yellow florescence under the uv-torch of filter paper previously exposed to the vapors from boiling plant material confirmed coumarins. Lastly, for detecting anthraquinones, the extract was dissolved in $1 \% \mathrm{HCl}$, then in benzene; the extract showed pinkviolet to reddish color with ammonium hydroxide.

\section{Castor oil-induced diarrhea}

Mice were fasted for 24 hours before the experiment. Animals were housed in individual cages and divided in five groups, each containing 10 mice. The first group received saline $(10 \mathrm{~mL} / \mathrm{kg}$, p.o. $)$ and served as a negative control. The dose of the test extract $(100 \mathrm{mg} /$ $\mathrm{kg}$ ) was selected on trial basis and was given orally to a group. Another group of mice was treated with loperamide $(10 \mathrm{mg} / \mathrm{kg}$, p.o.), as a positive control. One hour after treatment, each animal received $10 \mathrm{~mL} / \mathrm{kg}$ of castor oil orally through a feeding needle. Afterward, the cages were inspected for the presence of diarrhea droppings; their absence was noted as a positive result, indicating protection from diarrhea at that time (Shah et al., 2011c).

\section{Rabbit jejunum}

The rabbit abdomen was cut opened and jejunum was dissected out, kept in normal Tyrode's solution as described previously (Gilani et al., 2005; Khan et al., 2011a). Each segment of about $2 \mathrm{~cm}$ length was suspended in $10 \mathrm{~mL}$ tissue bath containing Tyrode's solution ( $\mathrm{pH} 7.4$ ), maintained at $37^{\circ} \mathrm{C}$ and aerated with a mixture of $95 \% \mathrm{O}_{2}$ and $5 \% \mathrm{CO}_{2}$ (carbogen). The composition of Tyrode's solution was (mM): NaCl: 136.9, KCl: 
2.7, $\mathrm{MgCl}_{2} \cdot 6 \mathrm{H}_{2} \mathrm{O}: 0.5, \mathrm{NaHCO}_{3}: 11.9, \mathrm{NaH}_{2} \mathrm{PO}_{4} \cdot 2 \mathrm{H}_{2} \mathrm{O}$ : $0.32, \mathrm{CaCl}_{2}$ : 1.8 , and glucose: 5.05. One end of the segment was attached to the metallic tissue-hook and the other was attached by a cotton thread to an isotonic Bioscience transducer, connected to a Student oscillograph (Harvard Apparatus, Holliston, MA, USA). An initial load of $1 \mathrm{~g}$ was applied to each tissue and was allowed to equilibrate for $30 \mathrm{~min}$ before the addition of any drug. Following equilibration period, each preparation was then stabilized with sub-maximal concentration of ACh $(0.3 \mu \mathrm{M})$ at $3 \mathrm{~min}$ interval until constant responses were recorded. Under these experimental conditions, rabbit jejunum exhibits spontaneous rhythmic contractions, allowing testing of the relaxant (spasmolytic) activity directly without the use of any agonist. For elucidation of mechanisms of spasmolytic activity, high $\mathrm{K}^{+}(80 \mathrm{mM})$ and low $\mathrm{K}^{+}(20 \mathrm{mM})$ concentrations were used to depolarize the isolated tissues that lead to produce sustained contractions. The plant material was then added in a cumulative fashion to obtain concentration-dependent inhibitory responses (Shah et al., 2011a). The relaxation of isolated tissue preparations was expressed as percent of the control response mediated by added low and high $\mathrm{K}^{+}$concentrations.

\section{Bronchodilator activity}

Rats were anaesthetized with sodium thiopental (Pentothal, $80-100 \mathrm{mg} / \mathrm{kg}$, i.p.), then cannulated the tracheal tube and ventilated with volume ventilator (Miniature ideal pump, Bioscience, UK) adjusted at rate of 70-80 strokes/min to deliver $7-10 \mathrm{~mL} / \mathrm{kg}$ of carbogen gas (Khan et al., 2011b; Khan et al., 2012a). A polyethylene catheter was inserted into the jugular vein for drugs administration. Changes in airways resistance $(\mathrm{mmHg})$ were measured by pressure transducer (MLT-1199) connected to side arm of tracheal cannula and recorded by PowerLab $4 / 25$ with running chart software via Quad bridge amplifier (AD Instruments, Bella Vista, NSW, Australia). Bronchoconstriction was induced with carbachol $(100 \mu \mathrm{g} / \mathrm{kg})$, which was reversed within 7-10 min. The test drug was given to the animals 5-8 min prior to administration of carbachol. The responses were expressed as the percent reduction of the carbachol-induced bronchospasm.

\section{Guinea-pig trachea}

Trachea was dissected from guinea-pig, sacrificed by cervical dislocation and kept in normal Kreb's solution. The tracheal tube was cut into rings, 2-3 mm wide, each containing about two cartilages. Each ring was opened by a longitudinal cut on the ventral side opposite the smooth muscle, forming a strip with smooth muscle in the center and cartilaginous portions on the edges (Khan and Gilani, 2006). The preparation was mounted in $20 \mathrm{~mL}$ tissue bath containing Kreb's solution $(\mathrm{pH}$ $7.4)$, at $37^{\circ} \mathrm{C}$ and aerated with carbogen. The compo- sition of Kreb's solution was (mM): $\mathrm{NaCl}$ : 118.2, $\mathrm{NaHCO}_{3}:$ 25.0, $\mathrm{CaCl}_{2}: 2.5, \mathrm{KCl}: 4.7, \mathrm{KH}_{2} \mathrm{PO}_{4}:$ 1.2, $\mathrm{MgSO}_{4} .7 \mathrm{H}_{2} \mathrm{O}: 1.2$, and glucose: 11.7. A tension of $1 \mathrm{~g}$ was applied to the tracheal strips continuously throughout the experiment. The tissues were allowed to equilibrate for 1 hour before the addition of any drug. The carbachol $(1 \mu \mathrm{M})$ was used to obtain sustained contractions in respective preparations and the inhibitory effect of test substance was assessed by adding in a cumulative fashion. The presence of PDE inhibitory effect was evaluated indirectly through constructing isoprenaline-induced inhibitory concentration-response curves (CRCs) against carbachol-induced contractions in absence (control) and presence of plant material, as described previously (Gilani et al., 2009). Isometric responses were recorded on a PowerLab (AD Instruments, Australia).

\section{Acute toxicity test}

Mice were divided in groups of five mice each. The test was performed using increasing doses of the plant extract, given orally in $10 \mathrm{~mL} / \mathrm{kg}$ volume to different groups serving as test groups. Another group of mice was administered saline $(10 \mathrm{~mL} / \mathrm{kg}$, p.o. $)$ as negative control. The mice were allowed food ad libitum and kept under regular observation for lethality recorded after 24 hours.

\section{Statistical analysis}

The data expressed are mean \pm SEM and median effecttive concentrations $\left(\mathrm{EC}_{50}\right)$ with $95 \%$ confidence intervals (CI). The statistical parameters applied were Chi-square test for antidiarrheal assay and one-way analysis of variance followed by Dunnet's test for bronchodilatory activity. Difference of $p<0.05$ was considered statistically significant. Concentration-response curves were analyzed by non-linear regression using GraphPad program (GraphPAD, San Diego, CA, USA).

\section{Results}

M. alba was found to contain flavonoids, sterols, tannins and terpenes, while tested negative for rest of the classes. It exhibited protective effect against castor oilinduced diarrhea in mice. The negative control group (saline treated) did not show any protection against castor oil-induced diarrhea. Pretreatment of animals with plant extract showed $60 \%$ protection from diarrhea at $100 \mathrm{mg} / \mathrm{kg}$ ( $\mathrm{p}<0.05$ vs. saline group). Loperamide (10 $\mathrm{mg} / \mathrm{kg}$ ) showed complete $(100 \%)$ protection from diarrhea $(\mathrm{p}<0.01$ versus saline group) in positive control group (Table I). M. alba and cromakalim caused concentration-dependent relaxation of spontaneous contractions of rabbit jejunum preparations (Figure 1) with respective $\mathrm{EC}_{50}$ values of $5.7 \mathrm{mg} / \mathrm{mL}$ (4.1-7.9, 95\% $\mathrm{CI}, \mathrm{n}=5)$ and $34.2 \mu \mathrm{M}(30.1-38.9 ; \mathrm{n}=4)$. When tested 


\begin{tabular}{|c|c|c|c|}
\hline \multicolumn{4}{|c|}{ Table I } \\
\hline \multicolumn{4}{|c|}{$\begin{array}{c}\text { Effect of the crude extract of } M . \text { alba on castor oil- } \\
\text { induced diarrhea in mice }\end{array}$} \\
\hline Treatment (p.o.) & $\mathrm{n}$ & $\begin{array}{l}\text { Mice with } \\
\text { diarrhea }\end{array}$ & $\begin{array}{c}\% \\
\text { Protection }\end{array}$ \\
\hline $\begin{array}{l}\text { Saline }(10 \mathrm{~mL} / \mathrm{kg})+\text { cas- } \\
\text { tor oil }(10 \mathrm{~mL} / \mathrm{kg})\end{array}$ & 10 & 10 & 0 \\
\hline $\begin{array}{l}\text { M. alba }(100 \mathrm{mg} / \mathrm{kg})+ \\
\text { castor oil }(10 \mathrm{~mL} / \mathrm{kg})\end{array}$ & 10 & $4^{\mathrm{a}}$ & 60 \\
\hline $\begin{array}{l}\text { Loperamide }(10 \mathrm{mg} / \mathrm{kg}) \\
+ \text { castor oil }(10 \mathrm{~mL} / \mathrm{kg})\end{array}$ & 10 & $0^{\mathrm{b}}$ & 100 \\
\hline
\end{tabular}

against high $\mathrm{K}^{+}(80 \mathrm{mM})$-induced contractions, M. alba exerted weak inhibitory effect $(27 \%, \mathrm{n}=4)$ at highest tested concentration $(10 \mathrm{mg} / \mathrm{mL})$, while completely relaxed the contractions induced by low $\mathrm{K}^{+}(20 \mathrm{mM})$ with $\mathrm{EC}_{50}$ value of $7.2 \mathrm{mg} / \mathrm{mL}(4.0-9.9, \mathrm{n}=3)$. In presence of glibenclamide $(3 \mu \mathrm{M})$, the inhibition of low $\mathrm{K}^{+}(20 \mathrm{mM})$-induced contractions was prevented (Figure 2A). Similarly, cromakalim also caused glibenclamide-sensitive relaxation of the contractions induced by low $\mathrm{K}^{+}(20 \mathrm{mM})$ with $\mathrm{EC}_{50}$ value of $12.4 \mu \mathrm{M}(11.0-$ $18.5 ; \mathrm{n}=3)$, without any effect on high $\mathrm{K}^{+}(80 \mathrm{mM})$ induced contractions (Figure 2B), whereas, verapamil inhibited low $\mathrm{K}^{+}(20 \mathrm{mM})$ and high $\mathrm{K}^{+}(80 \mathrm{mM})$-induced contractions at a similar concentration range, with $\mathrm{EC}_{50}$ values of $0.3(0.2-0.6 ; \mathrm{n}=3)$ and $0.3 \mu \mathrm{M}(0.2-0.4 ; \mathrm{n}=3)$ respectively (Figure 2C). M. alba at the doses of 3,10 and $30 \mathrm{mg} / \mathrm{kg}$ caused $19.6 \pm 7.1,30.8 \pm 6.9$ and $42.5 \pm$ $2.5 \%(\mathrm{n}=5)$ respective suppression of carbachol $(100$ $\mu \mathrm{g} / \mathrm{kg}$ )-induced increase in inspiratory pressure of anaesthetized rats (Figure 3A). Cromakalim was used as a positive control, which inhibited the carbachol (100 $\mu \mathrm{g} / \mathrm{kg}$ )-mediated bronchoconstriction at $0.1,0.3$ and 1.0 $\mathrm{mg} / \mathrm{kg}$ by $6.2 \pm 3.1,36.0 \pm 4.7$ and $50.3 \pm 2.7 \%(\mathrm{n}=4)$ respectively (Figure 3B). M. alba was found devoid of

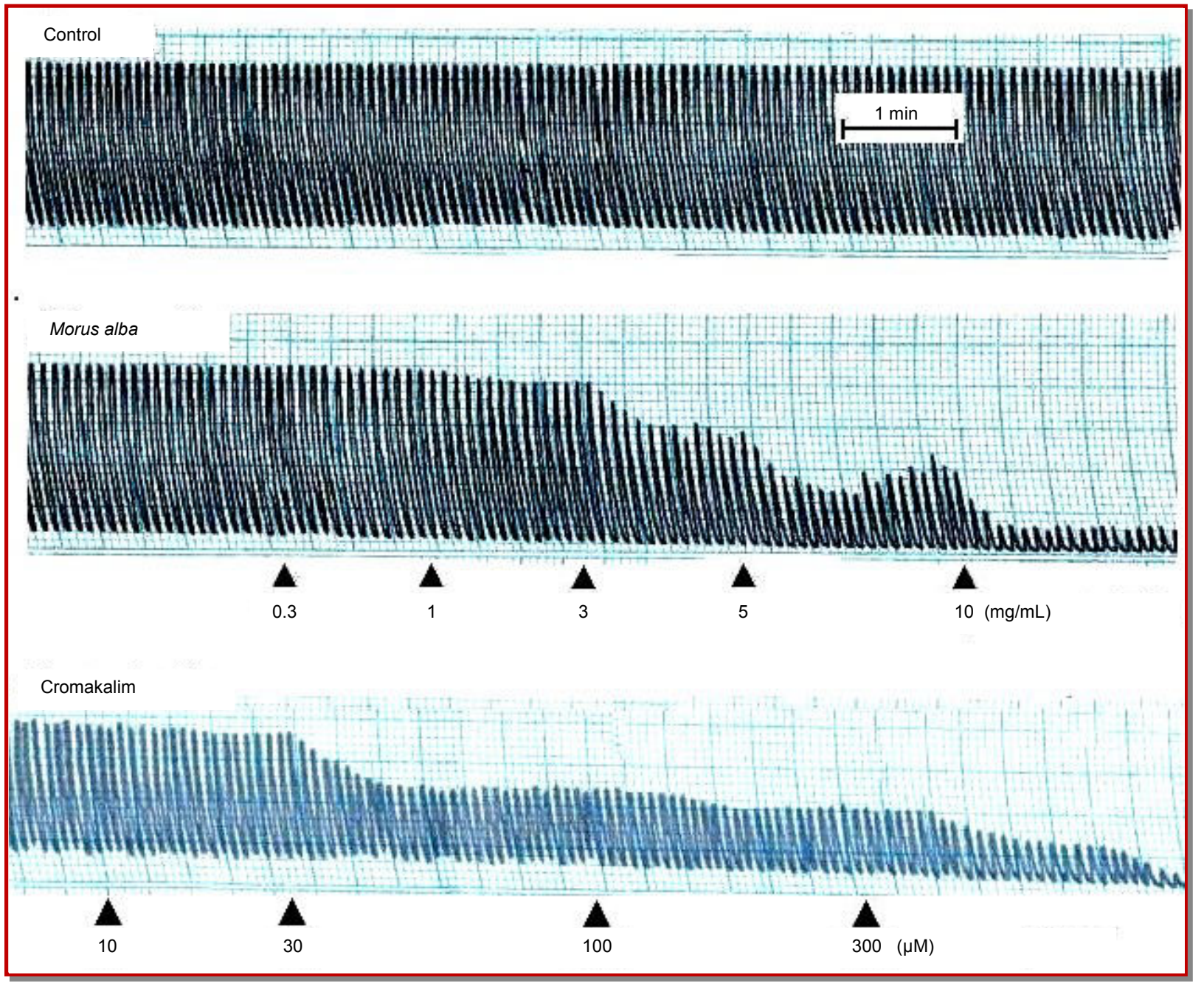

Figure 1: Tracings showing concentration-dependent relaxant effect of the crude extract of Morus alba and cromakalim on spontaneously contracting isolated rabbit jejunum preparations. Test material was added to the tissue bath in cumulative fashion and the concentrations shown are the final bath concentration 

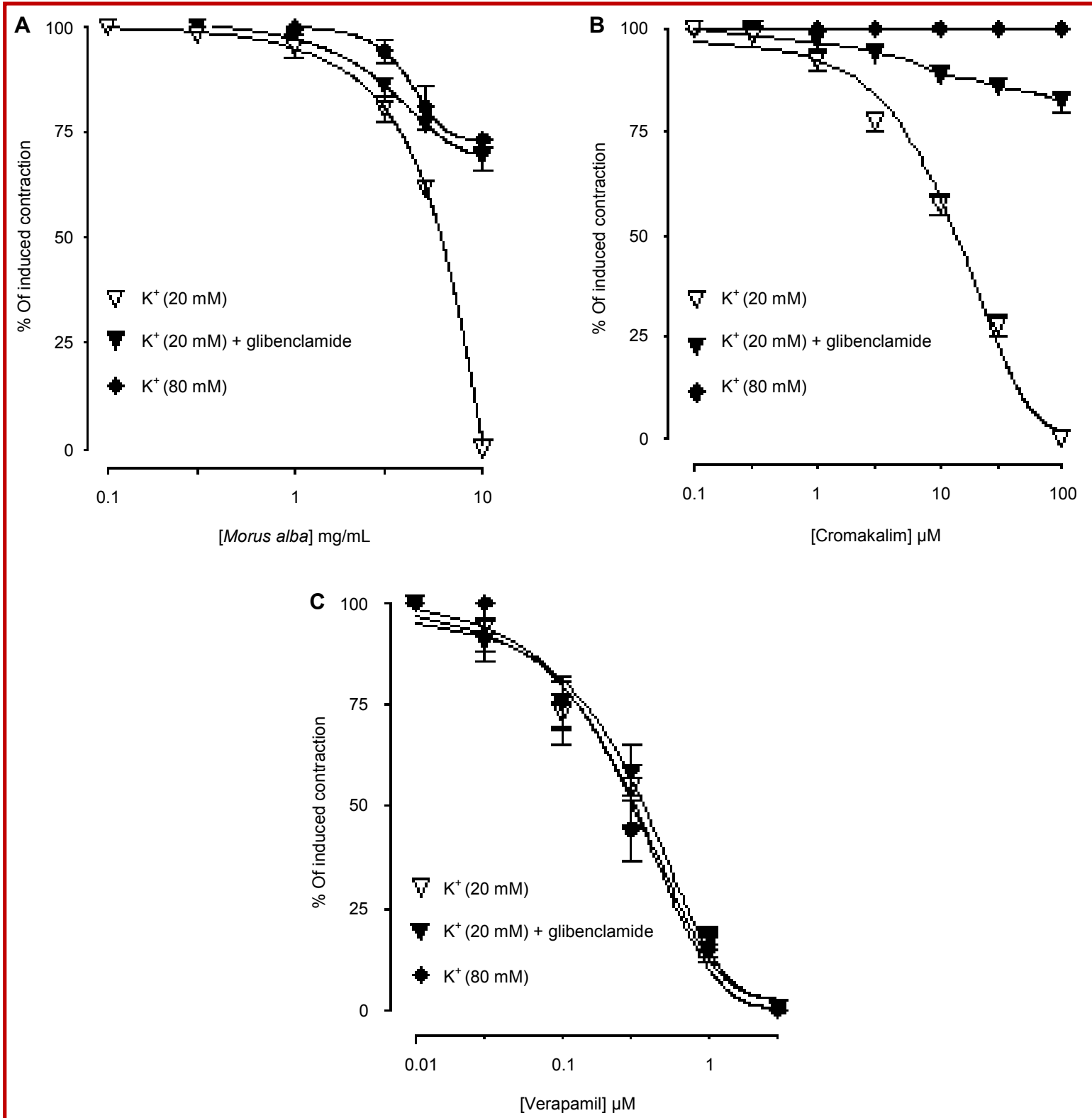

Figure 2: Concentration-response curves showing the comparison of (A) crude extract of Morus alba, (B) cromakalim and (C) verapamil for the inhibitory effect against low $\mathrm{K}^{+}(20 \mathrm{mM})$ in the absence and presence of glibenclamide $(3 \mu \mathrm{M})$ and high $\mathrm{K}^{+}(80 \mathrm{mM})$ induced contractions in isolated rabbit jejunum preparations. Values shown are mean $\pm \mathrm{SEM}, \mathrm{n}=3-4$

any stimulant action when screened on the resting base of guinea-pig trachea. When tested against the high $\mathrm{K}^{+}$ (80 $\mathrm{mM}$ )-induced contractions, M. alba exerted partial inhibitory effect $(37 \%, \mathrm{n}=4)$, while produced complete relaxation of low $\mathrm{K}^{+}(20 \mathrm{mM})$-induced contractions with $\mathrm{EC}_{50}$ value of $1.9 \mathrm{mg} / \mathrm{mL}(1.2-2.8 ; \mathrm{n}=3)$. In presence of glibenclamide $(3 \mu \mathrm{M})$, the relaxation of low $\mathrm{K}^{+}(20 \mathrm{mM})$ induced contractions was prevented (Figure 4). Pretreatment of tracheal preparations with $M$. alba shifted the isoprenaline-induced inhibitory CRCs to left (Figure $5 \mathrm{~A})$ in concentration-dependent manner (0.3 and 1.0 $\mathrm{mg} / \mathrm{mL}$ ), similar to that caused by papaverine (1.0 and
$3.0 \mu \mathrm{M})$ as shown in Figure 5B, exhibits potentiating effect. The three different groups of mice were given $M$. alba in the graded doses of 1,5 and $10 \mathrm{~g} / \mathrm{kg}$ respectively and the animals were observed for mortality after 24 hours of drug administration. The extract did not cause any mortality up to the dose of $10 \mathrm{~g} / \mathrm{kg}$.

\section{Discussion}

In view of $M$. alba medicinal use in hyperactive gut disorder, diarrhea, its extract was evaluated for the 


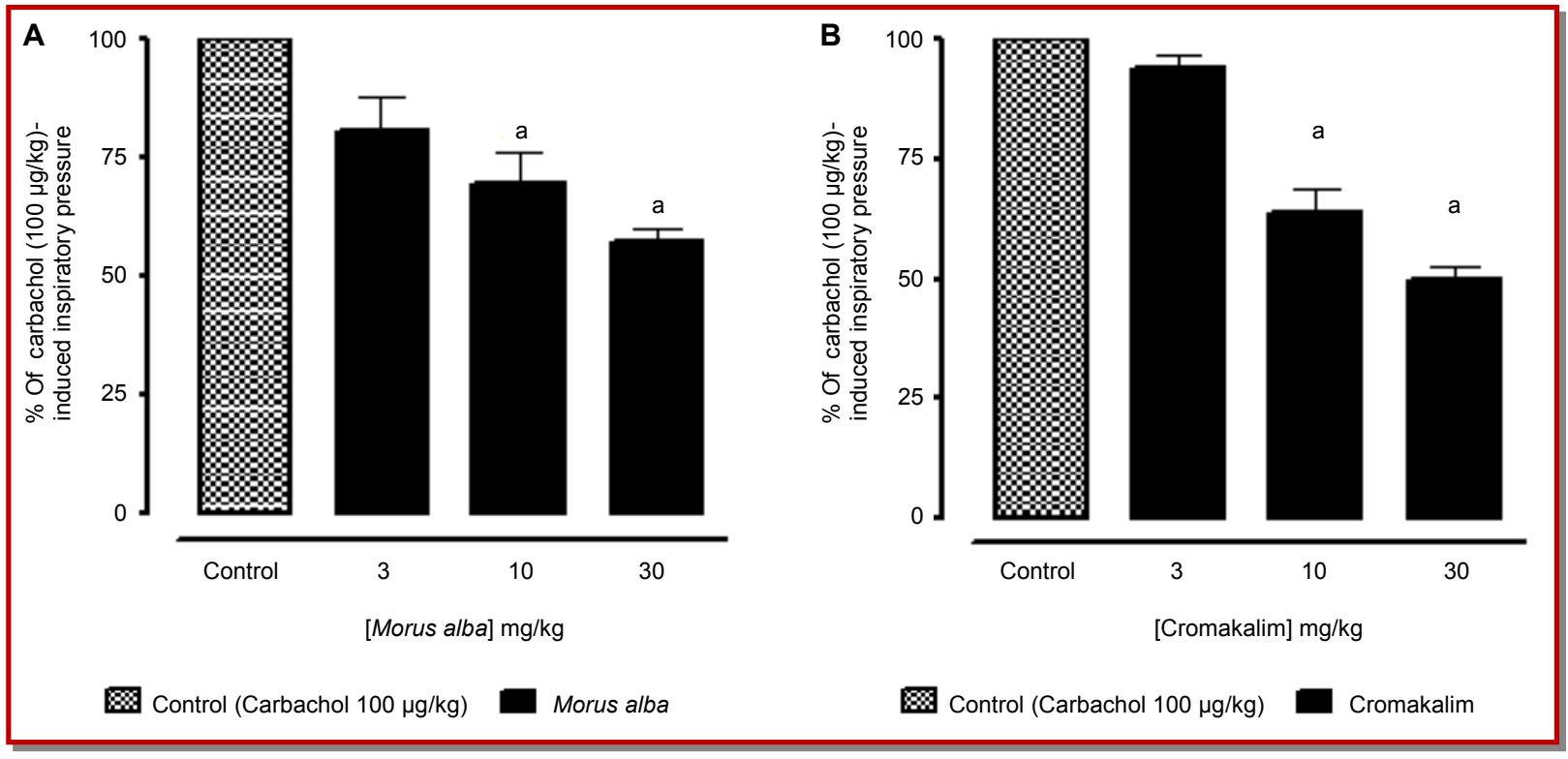

Figure 3: Dose-dependent suppressant effect of (A) crude extract of Morus alba and (B) cromakalim on carbachol-mediated bronchoconstriction in anaesthetized rats. Values shown are mean $\pm \mathrm{SEM}, \mathrm{n}=4-5$, a $\mathrm{p}<0.01$ vs. control (Carbachol), One-way analysis of variance, followed by Dunnett's test

possible antidiarrheal action in mice and the underlying pharmacological mechanism was elucidated using isolated intestinal tissues. In castor oil-induced diarrhea model, M. alba extract showed protective effect, like that caused by loperamide, a standard antidiarrheal drug (Reynolds et al., 1984). Castor oil induces diarrhea due to ricinoleic acid, formed during the hydrolysis of oil, which produces changes in transport of electrolytes and water, leading to generation of giant contractions of intestine (Iwao and Terada, 1962; Croci et al., 1997). Thus, a potential antidiarrheal may exhibit its effect by inhibiting bowel contractions. The antidiarrheal activity of $M$. alba following oral administration appears to be virtue of gastrointestinal relaxant components presence in M. alba.

To see its possible restrictive effect on gut motility, $M$. alba was studied in gut preparations to elucidate the pharmacodynamic aspects responsible for antidiarrheal effect. In spontaneously beating rabbit jejunum, M. alba relaxed the spontaneous contractions, thus showing an antispasmodic action. It is observed that spasmolytic effect of the medicinal plants is usually mediated through $\mathrm{Ca}^{++}$antagonist action (Ghayur and Gilani, 2005; Shah et al., 2011a; 2011b). To see whether the spasmolytic effect of M. alba is also mediated via similar mechanism, the extract was tested on high $\mathrm{K}^{+}$-induced contractions. However, its weak inhibitory effect against high $\mathrm{K}^{+}$, indicate that the spasmolytic effect is probably mediated through some other mechanism(s). When tested against low $\mathrm{K}^{+}$-induced contractions, it caused complete inhibition. The substance that selectively relaxes the contractions induced by low $\mathrm{K}^{+}$ is considered to be potassium channel opener, while
$\mathrm{Ca}^{++}$entry blockers inhibit both low and high $\mathrm{K}^{+-}$ induced contractions equally, and these experiments allow distinguishing $\mathrm{K}^{+}$channel activation from CCB mechanism (Hamilton et al., 1986; Kishii et al., 1992; Gopalakrishnan et al., 2004). The $\mathrm{K}^{+}$channel opening effect was confirmed, when the inhibition of low $\mathrm{K}^{+}-$ induced contractions was prevented in the presence of glibenclamide, a blocker of ATP-dependent $\mathrm{K}^{+}$channels (Frank et al., 1994 ; Davies et al., 1996). Cromakalim, a prototypical K $\mathrm{K}_{\mathrm{ATP}}$ channel opener (Brown and Raeburn, 1991; Deitmer et al., 1992; Moura et al., 1993) produced similar results to that of the M. alba extract, except that it produced no effect on high $\mathrm{K}^{+}$-induced contractions, while verapamil, a Ca ${ }^{++}$antagonist (Fleckenstein, 1977) inhibited low and high $\mathrm{K}^{+}$-induced contractions at similar concentrations. These results indicate that the antispasmodic effect of the M. alba is mediated possibly through a combination of dominant ATP-dependent $\mathrm{K}^{+}$ channel activation and weak $\mathrm{Ca}^{++}$-antagonist mechanisms. Potassium channel openers are relatively new class of drugs that comprises of a diverse group of molecules with wide range of potential therapeutic uses, like asthma, gastrointestinal spasm, diarrhea, hypertension and urinary incontinence (Empfield et al., 1995; Poggioli et al., 1995; Shieh et al., 2000). These compounds open $\mathrm{K}^{+}$channels, cause membrane hyperpolarization through the increase in $\mathrm{K}^{+}$efflux, thus causing decrease in the intracellular free $\mathrm{Ca}^{++}$ leading to smooth muscle relaxation (Cook, 1988; Quest, 1992).

Based on the medicinal use of $M$. alba in asthma and potential therapeutic use of $\mathrm{K}^{+}$channel openers in this disorder (Buchheit and Fozard, 1999; Pelaia et al., 2002; 


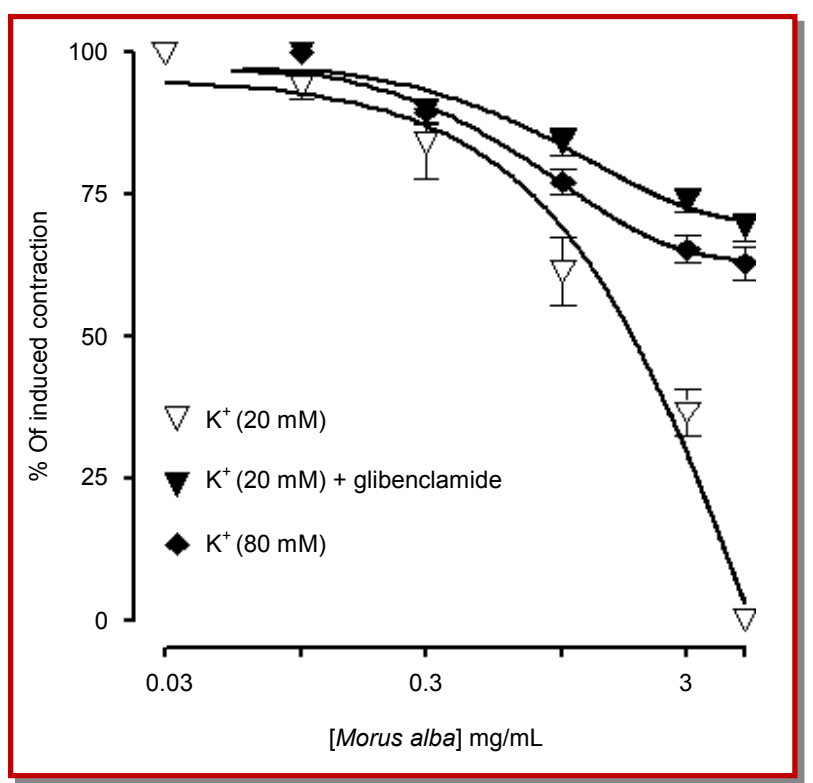

Figure 4: Concentration-response curves showing effect of the crude extract of Morus alba on low $\mathrm{K}+(20 \mathrm{mM})$ in the absence and presence of glibenclamide $(3 \mu \mathrm{M})$ and high $\mathrm{K}+(80 \mathrm{mM})-$ induced contractions in isolated guinea-pig tracheal preparations. Values shown are mean \pm SEM, $n=3-4$

Sheng and Jian, 2005), the extract was studied for possible bronchodilatory effect in anaesthetized rats, where $M$. alba dose-dependently suppressed the carbachol-evoked bronchospasm, like that caused by cromakalim. The plant extract was then studied in isolated trachea to investigate the possible modes of brochodilatory action. In guinea-pig tracheal preparations, like in jejunum, the $M$. alba extract caused glibenclamide-sensitive relaxation of low $\mathrm{K}^{+}$-induced contractions with partial effect on the contractions induced by high $\mathrm{K}^{+}$, indicating the involvement of $\mathrm{K}_{\text {ATP }}$ channel opening and partial CCB mechanisms in the $M$. alba bronchodilatory effect. Interestingly, the plant extract was found more effective in the trachea than the jejunum. Tissue selective behavior of $M$. alba could be due to $\mathrm{K}^{+}$gates activating component(s), as $\mathrm{K}_{\text {ATP }}$ channels are known to be heterogeneous (Rudy, 1988; Aguilar-Bryan et al., 1998; Jenkinson, 2006) and some $\mathrm{K}_{\text {ATP }}$ channel openers are tissue selective. For example, a second generation $\mathrm{K}_{\mathrm{ATP}}$ channel activator, rilmakalim is bronchial smooth muscle selective, while most of the first generation molecules, such as lemakalim and bimakalim seem to exhibit a greater potency in the vasculature (Weston and Edwards, 1992; Jacoby et al., 1993). We have experienced that plants with medicinal use in the overactive airways disorders, usually possess PDE inhibitory effect, co-exist with other spasmolytic mechanisms (Shah and Gilani, 2010; Khan et al., 2012b; Rehman et al., 2012). To investigate whether M. alba also exhibits PDE enzyme inhibition component(s), isoprenaline-inhibitory-CRCs were constructed against carbachol-induced contractions by pretreatment of tissues with M. alba, as PDE-inhibitors are known to potentiate the isoprenaline-inhibitory effect (Lorenz and Wells, 1983; Abdel-Haq et al., 2000). The presence of PDE-inhibitory effect in $M$. alba was confirmed when the plant extract potentiated isoprenaline relaxant effect by causing leftward shift of isoprenaline-induced inhibitory curves, similar to that caused by papaverine, a standard PDE inhibitor (Rang et al., 1999). These findings indicate that bronchodilator effect of $M$. alba is mediated through combined $\mathrm{K}_{\mathrm{ATP}}$ channel opening, PDE inhibition and weak CCB pathways, hence provides sound mechanistic basis for its application in airways hyperactivity disorders. The PDE inhibitors are known to cause bronchodilatation by increasing intracellular level of cAMP and have been used for several decades in treatment of asthma (Weinberger and Hendeles, 1996; Barnes, 2006). Another possible explanation for the more affectivity of the plant extract in the trachea could be that $\mathrm{K}^{+}$channel activating and PDE-inhibitory components may exert synergistic interaction in airways, though species difference cannot be ruled out.

The results of preliminary phytochemical analysis reveal that $M$. alba extract contains flavonoids, sterols, tannins and terpenes. The flavonoids are well known for their spasmolytic activity (Di Carlo et al., 1993; Pietta, 1998; Ghayur et al., 2007) and the presence of such class of compounds in $M$. alba are likely to contribute in its antispasmodic and bronchodilatory effects, though the likely role of other constituents present in the plant cannot be ignored. In acute toxicity study, the extract was found safe up to the maximum dose $(10 \mathrm{~g} / \mathrm{kg})$ tested, which is in line with the wide therapeutic and nutritional use of M. alba.

In summary these data indicate that $M$. alba possesses combination of spasmolytic activities, channeled through various mechanisms, including $\mathrm{K}_{\text {ATP }}$ channel activation, weak $\mathrm{Ca}^{++}$antagonism and PDE inhibition. The predominant $\mathrm{K}^{+}$channel opening and mild $\mathrm{Ca}^{++}$ influx inhibition explains its antispasmodic action and combination of $\mathrm{K}_{\mathrm{ATP}}$ gates activation, PDE inhibitory and partial CCB effects account for tracheal relaxation. Thus the present study provides pharmacological basis for the medicinal use of $M$. albain hyperactive gut and respiratory disorders, like diarrhea and asthma. Moreover, the in vivo antidiarrheal and bronchodilatory activities prove effectiveness of the plant in such conditions and is a step forward towards the evidence based medicinal use of phytomedicine.

\section{Acknowledgement}

This study was supported in part by the Higher Education Commission of Pakistan, a PhD scholarship grant to Mr Najeeb -ur-Rehman. 

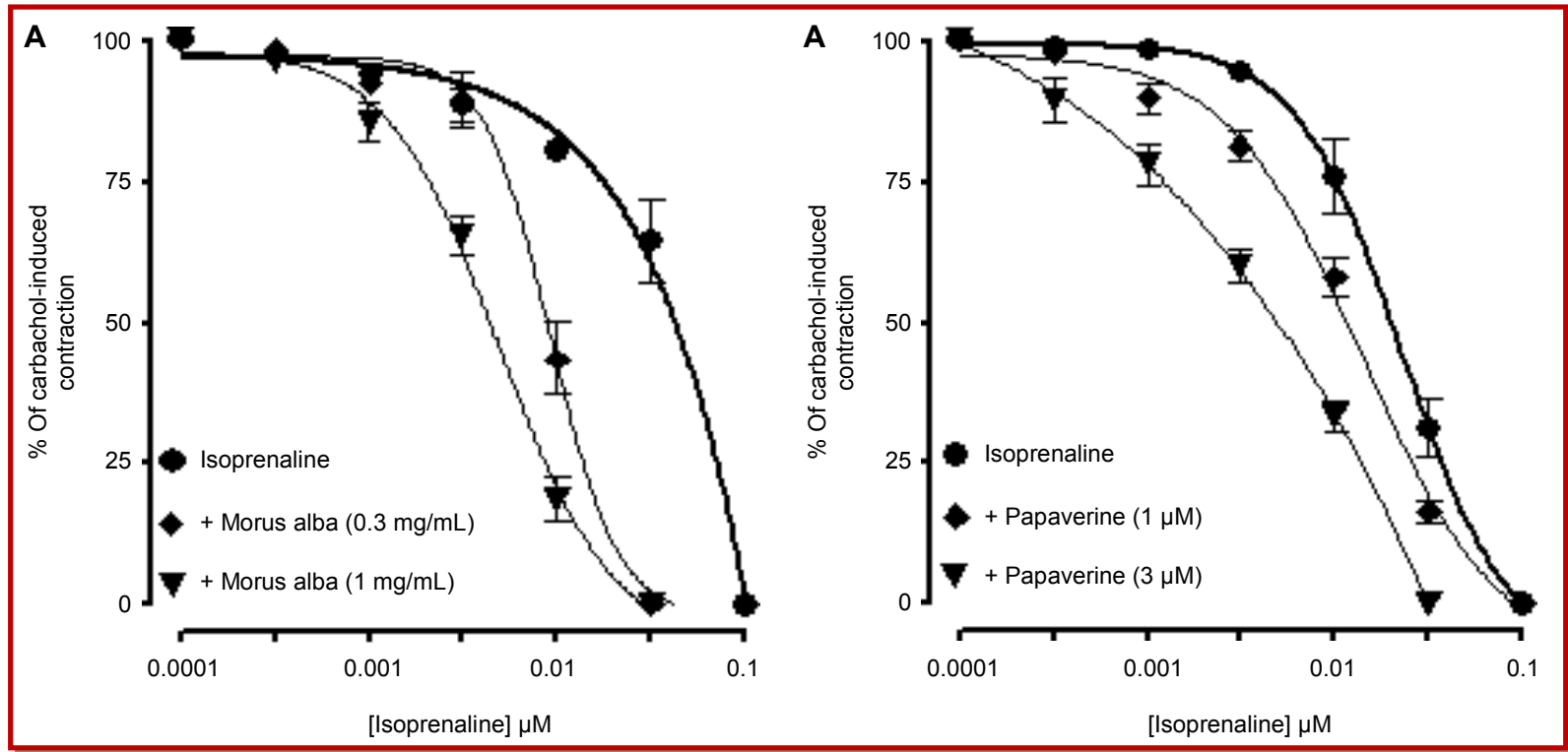

Figure 5: Inhibitory concentration-response curves of isoprenaline against carbachol-induced contractions in the absence and presence of different concentrations of (A) crude extract of Morus alba and (B) papaverine in isolated guinea-pig tracheal preparations. Values shown are mean \pm SEM, $n=4-5$

\section{References}

Abdel-HaqH, Cometa MF, Palmery M, Leone MG, Silvestrini B, Saso L. Relaxant effect of Hydrastis canadensis and its major alkaloids on guinea-pig isolated trachea. Pharmacol Toxicol. 2000; 87: 218-22.

Aguilar-Bryan L, Clement JP, Gonzalez G, Kunjilwar K, Babenko A, Bryan J. Towards understanding the assembly and structure of K $\mathrm{K}_{\text {ATP }}$ channels. Physiol Rev. 1998; 78: 227-45.

Baquar SR. Medicinal and Poisonous Plants of Pakistan. Printas, Karachi, 1989, p 291.

Barnes PJ. Drugs for asthma. Br J Pharmacol. 2006; 147: S297S303.

Baurin N, Arnoult E, Scior T, Do QT, Bernard P. Preliminary screening of some tropical plants for anti-tyrosinase activity. J Ethnopharmacol. 2002; 82: 155-58.

Bown D. Encyclopaedia of herbs and their uses. Dorling Kindersley, London, 1995.

Brown TJ, Raeburn D. RP 49356 and cromakalim relax airway smooth muscle in vitro by opening a sulphonylureasensitive $\mathrm{K}^{+}$channel: A comparison with nifedipine. J Pharmacol Exp Ther. 1991; 256: 480-85.

Buchheit KH, Fozard JR. $\mathrm{K}_{\mathrm{ATP}}$ channel openers for the treatment of airways hyperactivity. Pulm Pharmacol Ther. 1999; 12: 103-05.

Chen F, Nakashima N, Kimura I, Kimura M. Hypoglycemic activity and mechanisms of extracts from mulberry leaves and Cortex moriradicis in streptozotocin-induced diabetic mice. Yakugaku Zasshi. 1995; 115: 476-82.

Chiej R. Encyclopaedia of medicinal plants. MacDonald, 1984.

Choi EM, Hwang JK. Effects of Morusalba leaf extract on the production of nitric oxide, prostaglandin E2 and cytokines in RAW264.7 macrophages. Fitoterapia 2005; 76: 608-13.

Cook NS. The pharmacology of potassium channels and their therapeutic potential. Trends Pharmacol Sci. 1988; 9: 21-28.

Croci T, Landi M, Elmonds-Alt X, Le Fur G, Maffrand JP, Manara L. Role of tachykinins in castor oil-induced diarrhoea in rats. Bri J Pharmacol. 1997; 121: 375-80.

Davies MP, McCurrie JR, Wood D. Comparative effects of $\mathrm{K}^{+}$ channel modulating agents on contractions of rat intestinal smooth muscle. Eur J Pharmacol. 1996; 297: 249-56.

Deitmer P, Golenhofen K, Noack T. Comparison of the relaxing effects of cicletanine and cromakalim on vascular smooth muscle. J Cardiovasc Pharmacol. 1992; 20: 35-42.

Deshpande RS, Smitha B, Naveen H, Neelakanta NT. Cultivation of medicinal crops and aromatic crops as a means of diversification in agriculture (consolidated report) 2008, p 205.

DiCarlo G, Autore G, Izzo AA, Maiolino P, Mascolo N, Viola P, Diurno MV, Capasso F. Inhibition of intestinal motility and secretion by flavonoids in mice and rats: Structure-activity relationships. J Pharm Pharmacol. 1993; 45: 1054-59.

Doi K, Kojima T, Makino M, Kimura Y, Fujimoto Y. Studies on the constituents of the leaves of Morus alba L. Chem Pharm Bull. 2001; 49: 151-53.

Duke JA, Ayensu ES. Medicinal plants of China. Inc, 1985.

Edeoga HO, OkwuDE, Mbaebie BO. Phytochemical constituents of some Nigerian medicinal plants. Afr J Biotechnol. 2005; 4: 685-88.

Empfield JR, Russell K, Trainor DA. Potassium channel openers: Therapeutic possibilities. Pharmaceut News. 1995; 6: 23-27. 
Fleckenstein A. Specific pharmacology of $\mathrm{Ca}^{++}$in myocardium, cardiac pacemakers and vascular smooth muscle. Rev Pharmacol Toxicol. 1977; 17: 149-66.

Frank H, Puschmann A, Schusdziarra V, Allescher HD. Functional evidence for a glibenclamide-sensitive $\mathrm{K}^{+}$ channel in rat ileal smooth muscle. Eur J Pharmacol. 1994; 271: 379-86.

Gayton AC, Hall JE. Textbook of medical physiology. $9^{\text {th }}$ ed. Philadelphia, WB Saunders, 1996, pp 95-103.

Ghayur MN, Gilani AH. Pharmacological basis for the medicinal use of ginger in gastrointestinaldisorders. Dig Dis Sci. 2005; 50: 1889-97.

Ghayur MN, Khan H, Gilani AH. Antispasmodic, bronchodilator and vasodilator activites of (+)-catechin, a naturally occurring flavonoid. Arch Pharmacol Res. 2007; 30: 970-75.

Gilani AH, Khan A, Jabeen Q, Subhan F, Ghafar R. Antispasmodic and blood pressure lowering effects of Valeriana wallichii are mediated through $\mathrm{K}^{+}$channel activation. J Ethnopharmacol. 2005; 100: 347-52.

Gilani AH, Shah AJ, Zubair A, Khalid S, Kiani J, Ahmed A, Rasheed M, Ahmad VU. Chemical composition and mechanisms underlying the spasmolytic and bronchodilatory properties of the essential oil of Nepeta cataria L. J Ethnopharmacol. 2009; 121: 405-11.

Gopalakrishnan M, Buckner SA, Shieh CC, Fey T, Fabiyi A, Whiteaker KL, Taber RD, Milicic I, Daza AV, Scott VES, Castle NA, Printzenhoff D, London B, Turner SC, Carroll WA, Sullivan JP, Coghlan MJ, Brune ME. In vitro and in vivo characterization of a novel naphthylamide ATP-sensitive $\mathrm{K}^{+}$ channel opener, A-151892. Br J Pharmacol. 2004; 143: 81-90.

Hamilton TC, Weir SW, Weston TH. Comparison of theeffects of BRL34915 and verapamil on electrical and mechanical activity in rat portal vein. Br J Pharmacol.1986; 88: 103-11.

Hong $\mathrm{CH}$, Hur SK, Oh OJ, Kim SS, Nam KA, Lee SK. Evaluation of natural products on inhibition of inducible cyclooxygenase (COX-2) and nitricoxide synthase (iNOS) in cultured mouse macrophage cells. J Ethnopharmacol. 2002; 3: 153-59.

Iwao I, Terada Y. On the mechanism of diarrhea due to castor oil. Jap J Pharmacol. 1962; 12: 137-45.

Jacoby HI, Tomko KA, Steffler C, Lee DKH. Vasorelaxant effect of the potassium cannel activator, RWJ 29009 is tissue selective. Life Sci.1993; 52: 233-38.

Jenkinson DH. Potassium channels-multiplicity and challenges. Br J Pharmacol. 2006; 147: S63-S71.

Khan A, Gilani AH. Selective bronchodilatory effect of Rooibos Tea (Aspalathuslinearis) and its flavonoid: chrysoeriol. Eur J Nutr. 2006; 45: 463-69.

Khan A, Rehman N, AlKharfy KM, Gilani AH. Antidiarrheal and antispasmodic activities of Salvia officinalis are mediated through activation of $\mathrm{K}^{+}$channels. Bangladesh J Pharmacol. 2011a; 6: 111-16.

Khan A, Jabeen Q, Gilani AH. Pharmacological basis for the medicinal use of cardamom in asthma. Bangladesh J Pharmacol. 2011b; 6: 34-37.
Khan M, Khan A, Rehman N, Gilani AH. Pharmacological explanation for the use of Juniperus excels in hyperactive gastrointestinal and respiratory disorders. J Nat Med. 2012a; 66: 292-301.

Khan M, Khan A, Rehman N, Gilani AH. Gut and airways relaxant effects of Carum roxburghianum. J Ethnopharmacol. 2012b; 141: 938-46.

Kim SY, Gao JJ, Kang HK. Two flavonoids from the leaves of Morus alba induce differentiation of the human promyelocytic leukemia (HL-60) cell line. Biol Pharm Bull. 2000; 23: 451-55.

Kishii KI, Morimoto T, Nakajima N, Yamazaki K, Tsujitani M, Takayanagi I. Effects of LP-805, a novel vasorelaxant agent, a potassium channel opener on rat thoracic aorta. Gen Pharmacol. 1992; 23: 347-53.

Lee SH, Choi SY, Kim H, Hwang JS, Lee BG, Gao JJ, Kim SY. Mulberroside $\mathrm{F}$ isolated from the leaves of Morus alba inhibits melanin biosynthesis. Biol Pharm Bull. 2002; 25: $1045-48$

Lorenz KL, Wells JN. Potentiation of the effects of sodium nitroprusside and isoproterenol by selective phosphodiesterase inhibitors. Mol Pharmacol. 1983; 23: 42430.

Moura RSD, Mello RFD, Daguinaga S. Inhibitory effect of cromakalim in human detrusor muscle is mediated by glibenclamide-sensitive potassium channels. J Urol. 1993; 149: 1174-77.

Nadkarni KM. Indian Materia Medica. Bombay, Popular Prakashan, 1976, p 816.

National Research Council. Guide for the care and use of laboratory animals. Washington, National Academy Press, 1996, pp 1-7.

Oh H, Ko EK, Jun JY, Oh MH, Park SU, Kang KH, Lee HS, KimYC. Hepatoprotective and free radical scavenging activities of prenylflavonoids, coumarin, and stilbene from Morus alba. Planta Med. 2002; 68: 932-34.

Pelaia G, Gallell L, Vatrella A, Grembiale RD, Maselli R, DeSarro GB, Marsico SA. Potential role of potassium channel openers in the treatment of asthma and chronic obstructive pulmonary disease. Life Sci. 2002; 70: 977-90.

Pietta P. Flavonoids in medicinal plants. In: Flavonoids in health and disease. Rive-Evans CV, Packer L (eds). New York, Marcel Dekker, 1998, pp 61-110.

Poggioli RA, Benelli R, Arletti E, Cavazzuti A. Bertolini: $\mathrm{K}^{+}$ channel openers delay intestinal transit and have antidiarrheal activity. Eur J Pharmacol. 1995; 287: 207-09.

Quest U. Potassium channel openers: Pharmacological and clinical aspects. Fund Clin Pharmacol. 1992; 6: 279-93.

Rang HP, Dale MM, Ritter JM. Pharmacology, $4^{\text {thedn. New }}$ York, Churchill Livingstone, 1999, pp 289-90.

Rehman NU, Khan A, Alkharfy KM, Gilani AH. Pharmacological basis for the medicinal use of Lepidium sativum in airways disorders. Evid-Based Complement Alter Med. 2012; $\mathrm{p} 8$.

Reynolds IJ, Gould RJ, Snyder SH. Loperamide: Blockade of 
calcium channels as a mechanism for antidiarrhoeal effects. J Pharmacol Exp Ther. 1984; 231: 628-32.

Rudy B. Diversity and ubiquity of $\mathrm{K}^{+}$channels. Neuroscience 1988; 25: 729-49.

Shah AJ, Gilani AH. Bronchodilatory effect of Acorus calamus is mediated through multiple pathways. J Ethnopharmacol. 2010; 131: 471-77.

Shah AJ, Zaidi MA, Sajjad H, Hamidullah, Gilani AH. Antidiarrheal and antispasmodic activities of Vincetoxicum stocksii are mediated through calcium channel blockade. Bangladesh J Pharmacol. 2011a; 6: 46-50.

Shah AJ, Begum S, Hassan SI, Ali SN, Siddiqui BS, Gilani AH. Pharmacological basis for the medicinal use of Psidium guajava leave in hyperactive gut disorders. Bangladesh J Pharmacol. 2011b; 6: 100-06.

Sheng LX, Jian XY. Potassium channels in airway smooth muscle and airway hyperactivity in asthma. Chin Med J. 2005; 118: 574-80.
Shieh CC, Coghlan M, Sullivan JP, Gopalakrishnan M. Potassium channels: Molecular defects, diseases and therapeutic opportunities. Pharmacol Rev. 2000; 52: 557-93.

Shinwari ZK, Khan AA, Nakaika T. Medicinal and other useful plants of District Swat Pakistan. Peshawar, Press, Al-Aziz Communications, 2003, p 78.

Usmanghani K, Saeed A, Alam MT. Indusyunic medicine. Karachi, University of Karachi Press, 1997, pp 295-96.

Weinberger M, Hendeles L. Theophylline in asthma. New Eng J Med. 1996; 334: 1380-88.

Weston AH, Edwards G. Recent progress in potassium channel opener pharmacology. Biochem Pharmacol. 1992; 43: $47-54$.

Wiart C. Medicinal plants of Southeast Asia. $2^{\text {nd }}$ ed, Malaysia, Pearson, 2002, p 40.

Williamson EM, Okpako DT, Evans FJ. Selection, preparation and pharmacological evaluation of plant material. John Wiley \& Sons, Chichester, 1998, pp 15-23. 